\title{
MFN2 Gene
}

National Cancer Institute

\section{Source}

National Cancer Institute. MFN2 Gene. NCI Thesaurus. Code C113227.

This gene is involved in mitochondrial fusion. 